\title{
The Impact of The Use of Social Media and Awareness of Religion Due to Influence The Role of The Parents and Teachers in Class Junior High School Student
}

\author{
Muhyani \\ Universitas Ibn Khaldun Bogor \\ yaniwongtegal@gmail.com
}

\begin{abstract}
This study is to find purposes: (1) the parents to influence of religious awareness, (2) the effect of parenting on the impact of using social media, (3) the influence of students' perceptions of the role of teachers in schools on religious awareness, (4) the influence of students' perceptions of the role of teachers in schools on the impact of social media users, (5) the influence of religious awareness on the impact of social media users. This research is field research is a social research in education. This research is categorized as survey research (Research Survey) where researchers do not make special treatment to respondents, researchers only distribute questionnaires to respondents. Furthermore, respondents were asked to fill in accordance with what they felt for the statement on the questionnaire. The population in this study were junior high school students in the cities of Depok and Bogor, while the sample in this study were several junior high school students in Depok and Bogor cities consisting of 427 students. Data are analyzed using structural equation models (structural equation models) known as LISREL. The analysis to be carried out in this study is path analysis. The results of this study indicate: (1) parenting directly influences religious awareness, (2) parenting directly influences the impact of social media use, (3) students' perceptions of the role of teachers in schools do not directly influence religious awareness , (4) students' perceptions of the role of teachers in schools directly influence the impact of social media users (5) religious awareness directly influences the impact of social media users
\end{abstract}

Keywords: Social Media, LISREL, Path Analysis.

\section{Introduction}

In this information era, which is characterized by the rapid development of digital technology, the generation of melinial information is so easy and fast, from good information to hoax information that can damage the user's mentality. The research conducted by Stollak et al. (2011) explained that the use of social networking and visiting multiple sites negatively affected student grades. The response from the questionnaire provided turned out that 63 percent of students get high numbers because they reduce their time using the web (Stollak et all., 2011). Another study conducted by Pituch also revealed that using Facebook for a long time made students' grades decrease condition. In addition, some students who use learning systems such as e-learning but do not use as they should, also result in not succeeding in getting satisfactory grades (Pituch \& Lee, 2006). 
In 1998, a survey of distance learning programs was conducted in tertiary institutions with 16 percent of students enrolled in distance learning programs failing to complete their studies (Pituch \& Lee, 2006). According to Sun (2008) in his writing also revealed that the e-learning market has increased by $35.6 \%$, but failed to use (Sun et al., 2008). These findings indicate progress in the use of information technology like a doubleedged knife, can be useful for users, can also plunge users.

The use of social media as revealed by Fodeman can make people post anything, many students who use Facebook post content that is embarrassing, insulting, and painful in writing, photos and videos that harm others (Fodeman \& Monroe, 2009). The research conducted by Al-Mukhaini, E.M, Al-Qayoudhi, O.W.S, Qaboos, S., Al-Badi, A.H ,. (2014) about the use of social networks or social media such as youtube, facebook, twitter, blogs in conducting social interactions in cyberspace. This study examines the usefulness and benefits of using social networks as well as the negative effects of developing classroom learning methods.

According to Shim (2011) E-learning becomes a great power tool and becomes a lifestyle and has a very strong impact on its users. Furthermore, he revealed that the use of E-learning individually can increase self-motivation (Shim et al., 2011). Research conducted by Nagy (2005) proves that because of the many benefits for users, it has increased the market demand for e-learning.

Research conducted by Siemens revealed that social media can develop, improve technology and learning content. This facility with various benefits by users is able to make a positive contribution. (Siemens \& Weller, 2011). Klamma et all, 2007 illustrates one of the most important uses of social networking is the ability to organize knowledge and learning by contacting various experts and experts to share knowledge, activities, concepts and others.

Despite the many benefits of using social media, the other side of excessive use of social media can also cause mental disorders. Daria Kuss and Mark Griffiths from the University of Nottingham in 2011, concluded that social media addiction is a mental disorder that requires professional care. They found that excessive use was due to social problems, low moral values, and less participation in communities not related to the internet.

According to Bekti, social media is the work of communication and information technology to become "foreigners" who, as a result of globalization, have become so freely present in the family, teach their users at any time, change their lifestyle, bring new habits, even say that the need for technology is a form of sophisticated hypnosis people who can change their behavior and how they communicate with others. (Bekti Istiyanto, 2016 p.58)

The BBC team's research states that social media affects people differently, depending on pre-existing conditions and personalities. In other words social media is like a double-edged knife, one side contains bad and destructive elements, while the other side has many benefits and goodness that can be obtained through social media. Personality is influenced by religious awareness (Setiadi \& Muhyani, 2016). Religious awareness and mental health are influenced by the care of parents and teachers in 
schools (Muhyani, 2012). In connection with the background above, this study aims to determine the effect of parenting and teacher care on religious awareness and student social media use.

\section{Literature Review}

\subsection{Social Media}

Social media is an online media, where users can easily participate, share, and create content including: blogs, social networks, wikis, forums and the virtual world. Social media is an online media that supports social interactions using web-based technology that converts communication into an interactive dialogue. (Cahyono, 2016)

Social media is basically a form that is not much different from the existence and workings of computers. Three forms of socializing such as introduction, communication, and cooperation can be analogous to the workings of computers that also form a system as a system exists between individuals and society. (Mulawarman, 2017)

Social media is a site where everyone can create a personal web page, then connect with friends to share information and communicate based on the internet. Social media invites anyone who is interested in participating by contributing and feedback openly, giving comments, and sharing information in a fast and unlimited time. (Cahyono, 2016)

Ologie (2013) there are 4 models of social media use: (1) building community; (2) utilizing various tools and transforming them into useful information; (3) share with others; (4) looking for what is desired. Social media makes its users more motivated to learn especially at the level of higher education (Fardoun et al., 2012).

\subsection{Religious Awareness.}

Religious awareness (religiosity) is manifested in various aspects of life, diversity does not only occur when a person performs his religious rituals, but also when doing other activities that are driven by supernatural powers. Not only is it related to activities that appear and can be seen by the eye, but also activities that do not appear and occur in one's heart. Therefore the problem of one's religious awareness will cover various sides or dimensions (Muhyani, 2012: 54-55)

People who in their lives consistently practice their religious teachings in all aspects of their life are called having high mental health. One of the characteristics of someone who has religus awareness is to carry out economic, social, political or any activities in order to worship God. (Muhyani, 2012)

For someone who has a high religious awareness, every step taken is not only because of humans, but only wants to get the pleasure of the Khaliq. He always looks good at what he gets, if what is obtained is something that is pleasing he will be grateful, whereas if what is obtained is something that is not pleasant even does not satisfy what he wants then he will be patient. So that he will avoid stress and always be happy in facing all the problems of his life, and always optimistic in carrying out all his 
life activities. As a result he will live happier because he feels close to Allah SWT, and he believes that what is given by Allah SWT always contains goodness.

\subsection{Parenting Patterns from Parents}

Every parent would want their children to grow up to be perfect children, both physically and mentally, so parents always try to fulfill all their children's needs, both physical such as eating, drinking, health, etc. and mentally like affection, attention, etc. This is like what Baumrind revealed that the single most important influence on most adolescents is trying to complete their developmental tasks in imitation of their parents' identities. (Muhyani, 2012). Similarly, the father as a parent is an important figure in the family has a very decisive role in the mental development of a positive child in the family. Any activity that is usually done by fathers such as ways of behaving, views, values, norms, and beliefs will be the basis of the formation of behavior, values, and beliefs for children. (Muhyani, 2012)

Being a parent is not easy, so if someone has made the decision to become a parent, he should have understood and realized the functions and responsibilities of parents from the beginning. Bigner said that being a parent also means being a teacher and caregiver. Parents are not only responsible for feeding, clothing, and raising children, but also have to carry out their functions to educate their knowledge and skills so that children become adults who are independent and useful for their community (Muhyani, 2012).

\subsection{The Role of Teachers in Schools}

A professional teacher is required with a number of minimum requirements, including having an adequate professional education qualification, having scientific competence in accordance with the field he is engaged in, having good communication skills with his students, having a creative and productive spirit, having a work ethic and high commitment to his profession, and always carry out self-development in a continuous manner (continuous improvement) through professional organizations, the internet, books, seminars, and the like. From the requirements to become a teacher above, the task of a teacher is no longer knowledge based, as is now done but more competency based, which emphasizes the optimal mastery of scientific concepts and engineering based on ethical and moral values. Consequently, a teacher no longer uses the one-way communication that is now being done, but creates a conducive classroom atmosphere so that there is a democratic two-way communication between teacher and student. This condition is expected to explore the creative potential of students. With the professionalization of teachers, the future teachers do not appear as teachers (teachers), such as their prominent functions so far, but switch as coaches, counselors, and learning managers. (learning manager) (Indra Djati, 2005)

According to Saudih in Muhyani (2012) Education is basically a core interaction between educators (teachers) and students. In this interaction the educator (teacher) plays a key role for the ongoing education activities. Without classes, buildings, 
equipment and so on the education process can still work even in an emergency, but without the teacher the education process is almost impossible to walk.

\section{Method}

\subsection{Types of research}

The research that will be carried out is Applied Research where the researcher wants to know the contribution of parenting style, the role of the teacher in the school towards the Religious Awareness and Use of Social Media students, so as to provide understanding to the community about the importance of the role of parents and teachers in value planting religious as a provision in utilizing the advancement of information technology.

This research is a Social Research in the field of education and is a Field Research where researchers directly look for data in the field. This research category is Survey Research (Research Survey) so that researchers do not make changes (there is no special treatment) on the variables studied.

\subsection{Research Variable}

In this study there are two variables, namely the independent variable, because the processing of this study uses structural equation models (structural equation models), so the designation for independent variables is commonly known as the exogenous variable, the dependent variable (dependent variable) the usual term used as an endogenous variable. In operation these variables are defined as follows:

\subsection{Independent variable}

Free variables are also referred to as causative or exogenous variables, in the context of this study consists of two variables, namely: variable parenting parents and teacher's role in school.

\subsection{Endogenous variable}

Dependent variable or dependent variable also called endogenous variable in this study consists of two variables, namely variables: Religious awareness (religion), and Use of Social Media.

\subsubsection{Population and Samples}

The population in this study were junior high school students in Depok and Bogor cities, while the samples in this study were:

\subsubsection{Data}

The research data was obtained through twice the first retrieval conducted at Nururrahman Junior High School which was used for Instrument Validation, the second taking in the targeted schools for hypothesis testing. The research data collection was 
carried out by using four research instruments, namely: Parenting style, The role of teachers in schools, Religious awareness, and Misuse of social media compiled based on supporting constructs.

Test the validity and reliability of the instrument of this study was carried out using SPSS for Windows software. For SPSS devices, it is used to determine the validity and reliability of items.

The method of collecting data in this study was a survey method using a questionnaire. Questionnaire is a technique of data collection that is done by giving a written statement to the respondent to answer (Sugiono, 2002). The questionnaire or instrument is given directly to the respondent. Data was collected using a closed questionnaire based on indicators of the variables developed in this study.

Data comes from student perceptions (respondents) of the statement submitted. To get the value of students' perceptions using a questionnaire using a Likert scale measurement. This scale is often called the attitude scale, which is the attitude of agree / conformity and disagree / according. In this study the scores used were five such as the following table 1 .

Table 1. Instrument Item Assessment.

\begin{tabular}{ccc}
\hline Score & Criteria & Poin \\
\hline 1 & Strongly agree & 5 \\
\hline 2 & Agree & 4 \\
\hline 3 & Less Agree & 3 \\
\hline 4 & Disagree & 2 \\
\hline 5 & Strongly disagree & 1 \\
\hline
\end{tabular}

The results of the instrument trial are as follows:

Table 2. Instrument Reliability Data.

\begin{tabular}{clll}
\hline No & Instrument & Number of Item & $\begin{array}{c}\text { Reliability } \\
\text { (Cronbach's Alpha) }\end{array}$ \\
\hline 1. & $\begin{array}{l}\text { Parenting Patterns from } \\
\text { Parents }\end{array}$ & 26 & 0.892 \\
\hline 2. & The Role of Teachers & 26 & 0.896 \\
\hline 3. & Religious Awareness & 15 & 0.786 \\
\hline 4. & The abuse of Social Media & 22 & 0.833 \\
\hline
\end{tabular}

\subsubsection{Data analysis}

Data analysis and processing techniques using structural equation models (structural equation models) known as LISREL The analysis to be carried out in this study is path analysis as follows: 


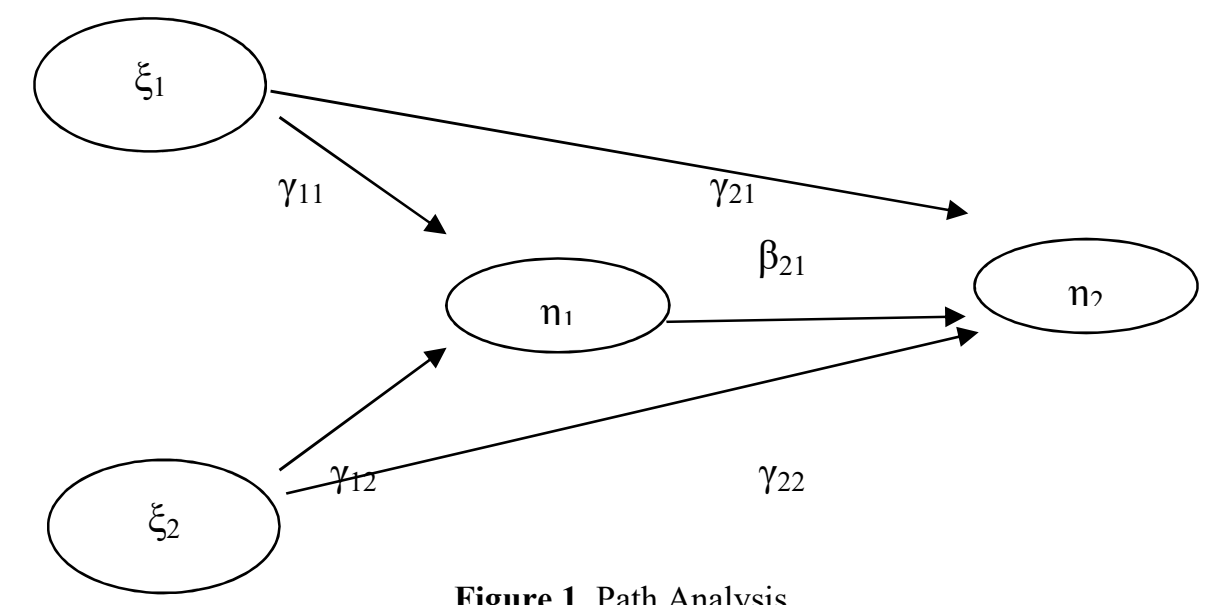

Figure 1. Path Analysis

There are two exogenous variables, namely parenting $(\xi 1)$, and the role of school ( $\xi 2)$ and there are two endogenous variables namely religious awareness $(\eta 1)$ and Social Media Utilization $(\eta 2)$. Straight lines whose ends are given arrows from exogenous variables directed to endogenous variables are denoted by letters $\gamma$, while straight lines whose ends are given arrows originating from endogenous variables one to endogenous variables the other symbolized by the letter $\beta$. Each relationship represented by an arrow is represented by a subscript coefficient in the form of two numbers such as $\gamma 12$ or $\beta 21$. The relationship shown by the symbol $\gamma 12$ shows the relationship of the exogenous variable to the first number endogenous variable in front (1) shows the endogenous variable $(\eta 1)$ while the second number (2) of the line originates from exogenous variables $(\xi 1)$. So the line denoted by menunjukkan 12 indicates the effect or impact of the exogenous variable $(\xi 1)$ on the endogenous variable $(\eta 1)$. While the line represented by $\beta 21$ shows the effect or impact of the endogenous variable $(\eta 1)$ on other endogenous variables $(\eta 2)$.

In this study the structural equation model can be described as follows:

$$
\left[\begin{array}{c}
\eta_{1} \\
\eta_{2}
\end{array}\right]=\left[\begin{array}{ll}
0 & \beta_{12} \\
& \\
0 & 0
\end{array}\right]\left[\begin{array}{l}
\eta_{1} \\
\eta_{2}
\end{array}\right]+\left[\begin{array}{lll}
\gamma_{11} & \gamma_{12} & \\
\gamma_{21} & \gamma_{22} & \xi_{\xi_{2}}
\end{array}\right]+\left[\begin{array}{l}
\zeta_{1} \\
\\
\zeta_{2}
\end{array}\right]
$$

\subsubsection{Research hypothesis:}

1. $\mathrm{H} 0=$ Parenting is not able to directly prevent the negative effects of using social media.

$\mathrm{Ha}=$ parenting parents can directly prevent the negative impact of using social media

2. H0 = Parenting people are not able to directly instill religious awareness in their children

$\mathrm{Ha}=$ parenting parents can instill religious awareness in their children

3 . $\mathrm{H} 0=$ the role of teachers in schools is not able to directly prevent the impact of using social media.

$\mathrm{Ha}=$ the role of the teacher in the school is able to prevent directly the negative impact of using social media 
4. $\mathrm{H} 0=$ the teacher's role in the school is not able to directly instill religious awareness in his students.

$\mathrm{Ha}=$ the role of the teacher in the school is able to instill religious awareness in his students.

5. $\mathrm{H} 0=$ Religious awareness of students is not able to prevent the negative impact of using social media in learning.

$\mathrm{Ha}=$ Students' religious awareness is able to prevent the negative impact of using social media in learning

Research and Discussion Results

Table 3. Research Data

\begin{tabular}{lllll}
\hline No & School's Name & Male & Female & Amount \\
\hline & SMP Negeri 1 Cibinong & & & \\
1 & Bogor & 29 & 53 & 82 \\
2 & SMP PGRI 1 Bogor & 22 & 28 & 50 \\
3 & SMP AL Azhar SB Bogor & 17 & 36 & 53 \\
4 & SMP Negri 2 Depok & 34 & 48 & 82 \\
5 & SMP Negeri 6 Depok & 48 & 52 & 100 \\
& SMPIT Nururrahman & & & \\
6 & Depok & 29 & 31 & 60 \\
\hline
\end{tabular}

The data is processed using Lisrel software, while the analysis uses the Alaysis path (Path analysis). The results of Path analysis are as follows.

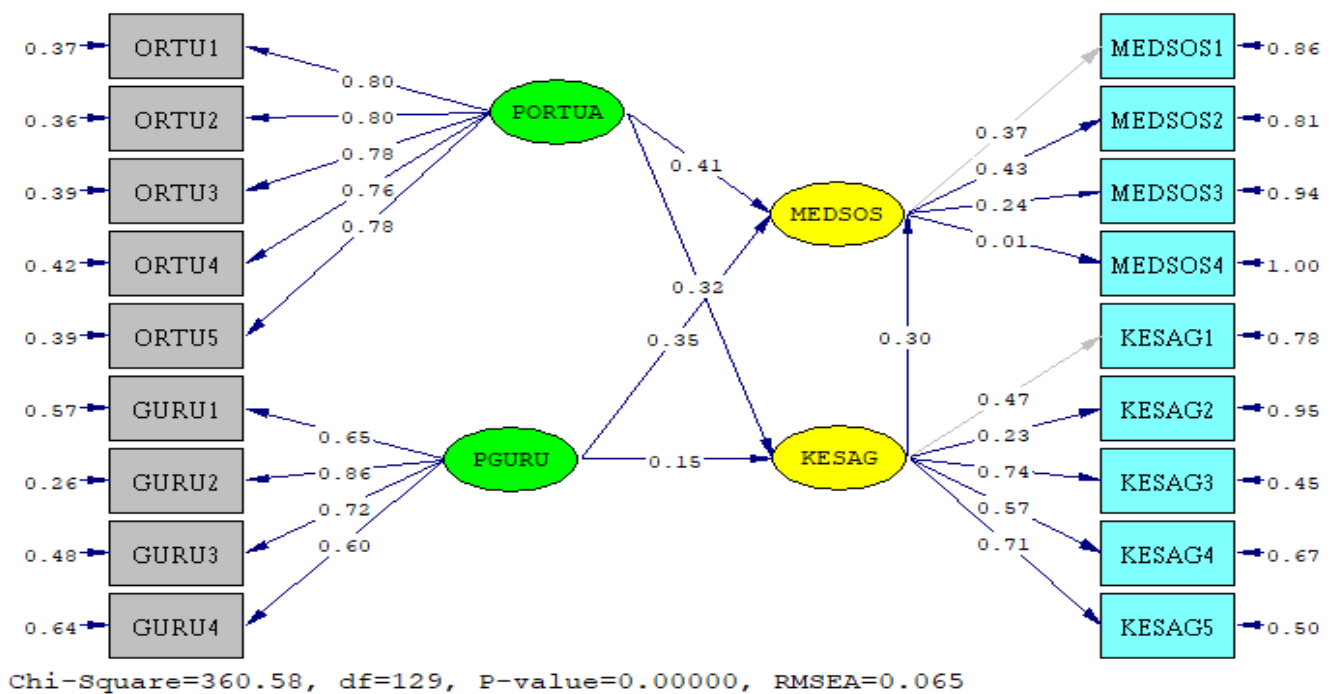

Figure 2. Path Standardized Solution Diagram

Information : 


\begin{tabular}{|c|c|}
\hline $\begin{array}{l}\text { PORTUA = Parenting Parents } \\
\text { Parent } 1=\text { Concern and support } \\
\text { Parent } 2=\text { Compliance } \\
\text { Parent } 3=\text { Induction } / \text { conditioning } \\
\text { Parent } 4=\text { role model } \\
\text { Parent } 5=\text { Engagement }\end{array}$ & $\begin{array}{l}\text { MEDSOS= Impact of using social } \\
\text { media } \\
\text { MEDSOS1 = Building a community } \\
\text { MEDSOS2 = Using information } \\
\text { MEDSOS3 = Information Sharing } \\
\text { MEDSOS4 = Search for what you } \\
\text { want }\end{array}$ \\
\hline $\begin{array}{l}\text { PGURU = The Role of Teachers in } \\
\text { Schools } \\
\text { Teacher } 1=\text { Aqidah } \\
\text { Teacher } 2=\text { Worship } \\
\text { Teacher } 3=\text { Intrapersonal } \\
\text { Teacher } 4=\text { Interpersonal }\end{array}$ & $\begin{array}{l}\text { KESAG }=\text { Religious Awareness } \\
\text { KESAG } 1=\text { Confidence } \\
\text { KESAG } 2=\text { worship } \\
\text { KESAG } 3=\text { Religious Knowledge } \\
\text { KESAG } 4=\text { appreciation } \\
\text { KESAG5 = Practice }\end{array}$ \\
\hline
\end{tabular}

From the picture above, almost all dimensions function properly, meaning that all dimensions in each variable play a good role, there are only a few that are less significant, namely the Medsos3 and Medsos4 dimensions, namely Sharing information and Seeking the desired variable in MEDSOS (Impact of Medsos Use), and the dimensions of KESAG 2, namely worship on the KESAG variable (Diversity Awareness).

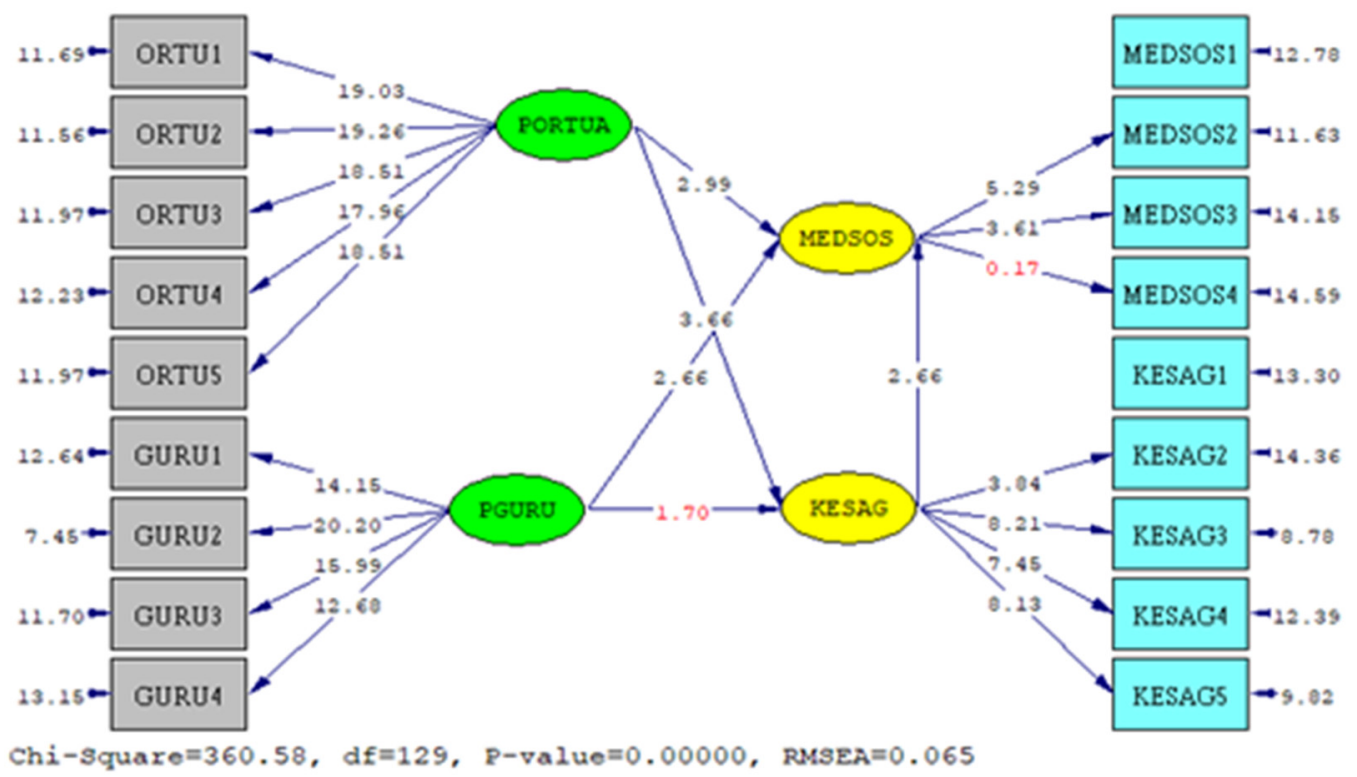

Figure 3. Inter-variable Structural Relationship Path Diagram 
Table 4. Corellation between research variables

\begin{tabular}{llll}
\hline Relations between Variables & Symbol & $\begin{array}{l}\text { Variables } \\
\text { Value }\end{array}$ & T Value \\
\hline The direct effect of parenting on religious awareness & $\gamma_{21}$ & 0.32 & 3.06 \\
\hline $\begin{array}{l}\text { The direct effect of parenting on the impact of social } \\
\text { media use os }\end{array}$ & $\gamma_{11}$ & 0.41 & 2.99 \\
\hline $\begin{array}{l}\text { The direct influence of the teacher's role on religious } \\
\text { awareness }\end{array}$ & $\gamma_{22}$ & 0.15 & 1.70 \\
\hline $\begin{array}{l}\text { The direct influence of the teacher's role on the } \\
\text { impact of the use of social media }\end{array}$ & $\gamma_{12}$ & 0.35 & 2.66 \\
\hline $\begin{array}{l}\text { The direct influence of religious awareness on the } \\
\text { impact of the use of social media }\end{array}$ & $\beta_{12}$ & 0.30 & 2.66 \\
\hline
\end{tabular}

From the table above, the following results are obtained:

Research Hypothesis Test:

1. $\mathrm{H} 0=$ Parenting is not able to directly prevent the negative effects of using social media.

$\mathrm{Ha}=$ parenting parents can directly prevent the negative impact of using social media $\mathrm{T}$ value is above 1.96 so Ho is rejected. So parenting is able to directly prevent the negative impact of using social media,

2. $\mathrm{H} 0=$ Parenting people are not able to directly instill religious awareness in their children

$\mathrm{Ha}=$ parenting parents can instill religious awareness in their children Values above 1.96 so Ho is rejected, so parenting is able to directly instill religious awareness in their children

3. $\mathrm{H} 0=$ the role of teachers in schools is not able to directly prevent the impact of using social media.

$\mathrm{Ha}=$ the role of the teacher in the school is able to prevent directly the negative impact of using social media $\mathrm{T}$ value is above 1.96 so Ho is rejected. So teachers in schools are able to directly prevent the negative effects of using social media,

4. $\mathrm{H} 0=$ the teacher's role in the school is not able to directly instill religious awareness in his students.

$\mathrm{Ha}=$ the role of the teacher in the school is able to instill religious awareness in his students. The $\mathrm{T}$ value is below 1.96 so $\mathrm{H} 0$ is accepted. So teachers in schools are not able to instill directly instilling religious awareness.

5. $\mathrm{HO}=$ Religious awareness of students is not able to prevent the negative impact of using social media in learning.

$\mathrm{Ha}=$ Students' religious awareness is able to prevent the negative impact of using social media in learning

6. Ho above 1.96 means that students' religious awareness is able to prevent the negative impact of using social media in learning 


\section{Discussion}

Of the five hypotheses there is only one hypothesis that is accepted, namely the 4th hypothesis which states the teacher's role in the school is not able to instill religious awareness directly to his students. This condition is a reality in the community that the school in this case played by the teacher has not been able to instill religious awareness in the students, this condition is probably due to the still dominant learning activities that focus on cognitive aspects, while the affective and psychomotor aspects of students are lacking. This situation must be realized by all education stakeholders, especially teachers, that the importance of giving a greater portion of the affective and psychomotor aspects in learning activities so that the values taught in religious teachings are able to be carried out well by the students.

\section{Bibliograph}

[1] Bekti Istiyanto, Telepon Genggam dan Perubahan Sosial, (Studi kasus dampak negatif media komunikasi dan informasi bagi anak-anak di kelurahan Bobosan Purwokerto Kabupaten Banyumas). Ilmu Komunikasi Fisip Universitas Jenderal Soedirman. Jurnal Komunikasi. 01, 2016.

[2] Cahyono, Anang Sugeng (2016), Pengaruh Media Sosial TerhadapPerubahan Sosial Masyarakat di Indonesia www.jurnal-unita.org /index.php/publiciana/ article/download

[3] Indra Djati Sidi (2001), Menuju Masyarakat Belajar Menggagas Paradigma Baru Pendidikan, Jakarta: Paramadina dan Logos.

[4] Jessica Brown, Is social media bad for you the evidence and the unknownd. BBC Future. www.bbc.com diunduh tanggal 12-05-2018 pukul 21.17.

[5] Joreskog, Karl dan Sorbom, Dag (1998), LISREL.8: Structural Equation Modeling wit the SIMPLIS Command Language, Chicago,

[6] Joreskog, Karl dan Sorbom, Dag (1998), LISREL.8: User's Reference Guide, Chicago,

[7] Kerlinger, Fred N., (2002) Asas-Asas Penelitian Behavioral (Drs. Landung R. Simatupang), Yogyakarta: Gadjah Mada University Press,.

[8] Muhyani.(2012). Pengaruh Pengasuhan Orang Tua dan Peran Guru di Sekolah terhadap Kesadaran Beragama dan Kesehatan Mental. Jakarta: Direktorat Pendidikan Tinggi Islam, Kementerian Agama RI.

[9] Mulawarman dan Aldila Dyas Nurfitri, (2017), Perilaku Pengguna media sosial beserta implikasinya ditinjau dari Perspektif Psikologi Sosial Terapan. https://jurnal.ugm.ac.id/buletin psikologi.

[10] Pituch, K. A., \& Lee, Y. K. (2006). The Influence of system characteristic on elearning use. Computer \& Education, 222-224.

[11] Komariah. 2011.Model Pendidikan Nilai Moral.Jurnal Pendidikan Agama Islam Ta"lim Vol. 9 No. 1 - 2011.

[12] Muhtadi. 2012. Strategi untuk Mengimplementasikan Pendidikan Moral Secara Efektif di Sekolah. melalui: $\underline{\text { http://stafuny.ac.id.. }}$ 
[13] Murdiono. 2012. Metode Penanaman Nilai Moral Untuk Anak Usia Dini. Jurnal Kependidikan-Lemlit UNY. Melalui: http://staff.uny.ac.id. 10 Agustus 2017.

[14] Nikmah.2013.Dampak Penggunaan Handphone Terhadap Prestasi Siswa.E-Jurnal Volume 5. Surabaya: Dinas Pendidikan Kota Surabaya.

[15] Pasaribu. 2012. Evolusi Teknologi Telekomunikasi Bergerak:1G to 4G. melalui: http://parlinpasaribu.com.

[16] Perilaku Remaja di Kota Makasar. Jurnal Penelitian IPTEK-KOM. Vol 13

[17] Pratiwi, RC. 2010. Implikasi Situs Jejaring Sosial Facebook terhadap Prestasi Belajar Siswa Kelas 2 Siswa SMA Maearif NU Pandaan. Skripsi. Malang: UIN Imam Malik Ibrahim.

[18] Punaji. 2012 Metode Penelitian Pendidikan dan Pengembangan. Jakarta: Media Group.

[19] Purwanti dkk. 2013. Pengaruh Perkembangan Handphone Terhadap Moral Siswa Kelas IV SD Negeri 01 Kota Bengkulu. Tesis.,melalui http://repository.unib.ac.id. 2013.

[20] Simanjuntak, D. 2013. Peranan Teknologi Informasi dan Komunikasi dalam

[21] Sugiyono. 2011. Metode Penelitian Kualitatif Kuantitatif dan R\&B. Bandung: Alfa Beta.

[22] Utami, S. 2014. Pengaruh Penggunaan Teknologi Handphone terhadap Moral Siswa Studi Kasus di MI Muhammadiyah Gondang. Magelang Tahun Pelajaran 2013/2014. Thesis. Program Pascasarjana Sekolah Tinggi Agama Islam Negeri Salatiga.

[23] Veronika, D. 2013. Pengaruh Penggunaan Telepon Selular Sebagai Media Komunikasi Terhadap Sikap Siswa SMP Negeri 30 Samarinda. eJournal Ilmu Komunikasi. 2013. $12: 375-388$.

[24] Yudiningrum, FR. 2016. Efek Teknologi Komunikasi Elektronik bagi Tumbuh Kembang Anak. Jurnal Publikasi. https://eprints.uns.ac.id. Surakarta: Fakultas Ilmu Sosial dan Ilmu Politik Universitas Sebelas Maret.

[25] Zubaidi, A. (2005) Pengaruh Komponen Interpersonal dan Komponen Intrapsikis terhadap Perkembangan Moral, Disertasi, Jakarta: Program Pascasarjana Fakultas Psikologi Universitas Indonesia, 2005 